\title{
JOURNAL.RU
}

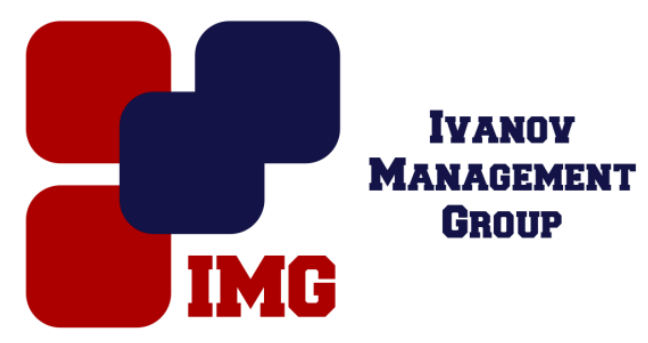

Костин К.Б., Горшков Н.В., Викулова М.А., Лукьянова В.О.

СГТУ им. Гагарина Ю.А.

Саратов, Россия

doi: $10.18411 / 1 \mathrm{j}-31-07-2017-37$

idsp 000001:1j-31-07-2017-37

\section{Исследование поверхности и состава стали марки 12Х18Н10Т с разными типами обработки}

Научный руководитель: Пичхидзе С.Я.

После каждого применения металлического медицинского инструмента необходимо проводить поверхностную стерилизацию и дезинфекцию поверхности, для предотвращения заражения пациентов бактериальными инфекциями [1].Вследствие этого, материалы, из которых изготавливаются инструменты, должны обладать рядом определенных физико-механических и антибактериальных свойств [2]. Многие медицинские инструменты производят из титановых сплавов [3], но чаще используют медицинские нержавеющие стали. Так как медицинская нержавеющая сталь уступает по свойствам титановым сплавам, то возникает необходимость дополнительной обработки её поверхности для улучшения свойств материала.

Цель настоящей работы: исследовать состав образцов медицинской нержавеющей стали марки 12X18Н10T с различными видами обработки .

Объекты и метод исследования: в качестве образцов были взяты пластины медицинской нержавеющей стали марки 12Х18Н10Т по ТУ 3-1002-77. Далее образцы подвергались тремя различными поверхностными обработками: пескоструйной обработкой электрокорундом A12O3, электрополированием, пассивацией и термическим оксидированием. Исследование поверхности готовых образцов проводилось на растровом электронном микроскопе Aspex Explorer (РЭМ). Изображения изучаемой поверхности и результаты 
энергодисперсионного анализа представлены на рисунке 1(а-б) и 1(в). Для рентгенофазного анализа (РФА) использовался дифрактометр Shimadzu XDR 6000, результат РФА показан на рис. 1(г).

Выводы: показано образование на поверхности стали 12X18Н10T оксидной пленки $\mathrm{Fe} 3 \mathrm{O} 4$ после термооксидирования и пассивации, которая обеспечивает антибактериальный эффект.

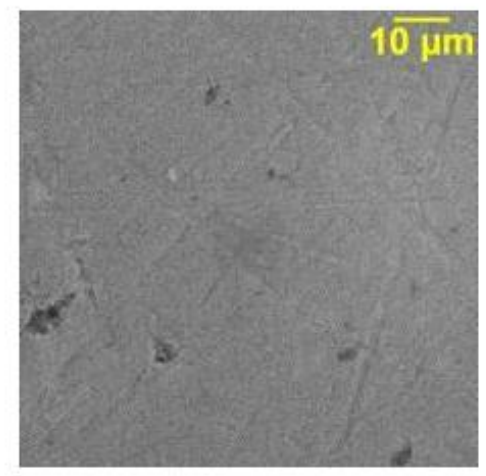

a)

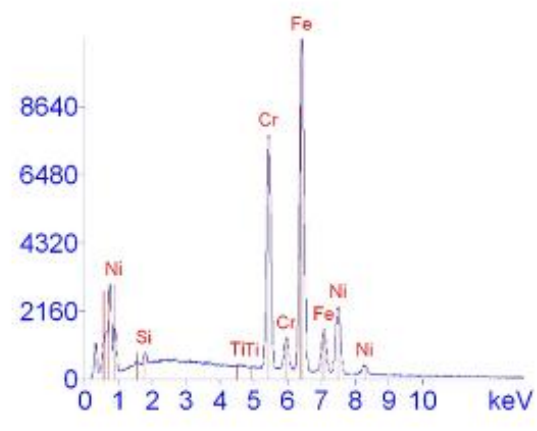

в)

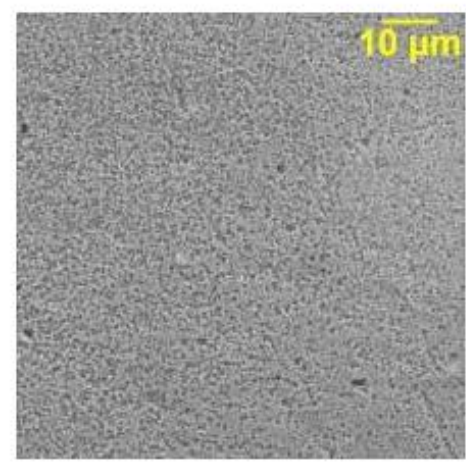

б)

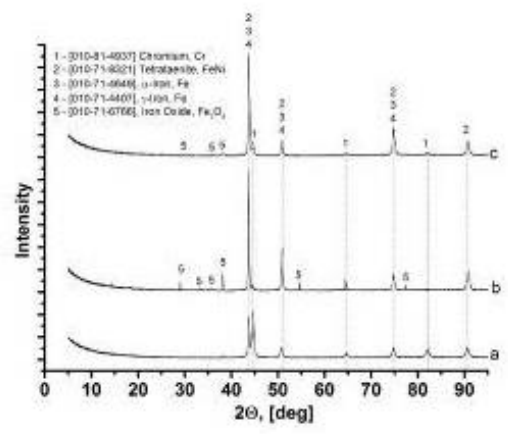

г)

Рис.1. Изображение поверхности образияа из стали 12X18Н10Т после термообработки (а) и после пассивации (б); ЭДРА поверхности образца после пассиваџии (в); РФА поверхности (2) стали $12 X 18 Н 10 T$ до (а) и после термического оксидирования (b) и пассивачии (c)

$* * *$

1. Zilberman M., Elsner J. J. Antibiotic-eluting medical devices for various application // Journal of Controlled Release. - 2008. - Vol. 130. №. 3. - P. 202-215.

2. Коллеров М. Ю. и др. Проблемы и перспективы применения титановых сплавов в медицине //Титан. - 2015. - №. 2. - С. 42-53.

3. Rai M., Yadav A., Gade A. Silver nanoparticles as a new generation of antimicrobials . Biotechnology advances. - 2009. - Vol. 27. - №. 1. - P. 76-83. 